\title{
PIT telemetry as a method to study the habitat requirements of fish populations: application to native and stocked trout movements
}

\author{
Amílcar Teixeira · Rui M. V. Cortes
}

(C) Springer Science+Business Media B.V. 2007

\begin{abstract}
Passive integrated transponder (PIT) technology was used to study the behaviour of fishes during the summer season in two headwater streams of northeastern Portugal. A total of 71 PIT tags $(12 \mathrm{~mm}$ long $\times 2.1 \mathrm{~mm}$ diameter $)$ were surgically implanted in $1^{+}$stocked (39) and native (32) brown trout of two size classes $(<20.0$ and $\geq 20.0 \mathrm{~cm}$ ). Eight independent antennae, connected to a multi-point decoder (MPD reader) unit, were placed in different microhabitats, selected randomly every 3 days during the observation period (29 August-9 September in Baceiro stream and 19 September-4 October in Sabor stream). The results confirmed this method as a suitable, labour efficient tool to assess the movement and habitat use of sympatric stocked and native trout populations. About $76.9 \%$ of stocked and $59.4 \%$ of native PIT tagged trouts were detected. Multivariate techniques (CCA, DFA
\end{abstract}

Guest editors: P. R. Almeida, B. R. Quintella,

M. J. Costa and A. Moore

Developments in Fish Telemetry

A. Teixeira $(\bowtie)$

CIMO-Escola Superior Agrária Bragança, Campus

Sta Apolónia, Apt. 1172, 5301-855 Bragança, Portugal

e-mail: amilt@ipb.pt

\section{R. M. V. Cortes}

Dep. Florestal, Universidade de Trás-os-Montes e Alto Douro, Apt. 1013, 5001-911 Vila-Real, Portugal e-mail: rcortes@utad.pt and classification tree) showed a separation in habitat use between the two sympatric populations. Stocked trout mainly used the microhabitats located in the middle of the channel with higher depths and without cover. Furthermore, these fishes displayed a greater mobility and a diel activity pattern different to native trout populations.

Keywords PIT tag - Brown trout - Stocking · Habitat use - Movement

\section{Introduction}

Stocking of hatchery-reared salmonids into natural water systems is still a fishery management tool frequently used to mitigate loss of stocks and enhance or restore fishery activities (Cowx, 1999). Increasing concerns have been expressed about the negative ecological and genetic effects of stocking on wild populations (White et al., 1995; Pearsons \& Hopley, 1999). For this reason, several studies were developed in order to understand the potential impacts resulting from the competitive interactions established (McMichael et al., 1999; Weber \& Fausch, 2005) and distinct methods were applied to study the habitat requirements, movements and fish behaviour (reviewed by Weber \& Fausch, 2003). But, all these methods, broadly grouped by Lucas \& Baras (2000) in two main 
categories: (1) capture-independent (e.g. underwater observations) and (2) capture-dependent (e.g. mark-recapture and telemetry techniques), present some limitations (Heggenes et al., 1990; Bridger \& Booth, 2003). Recent technology based on radiotelemetry has been widely used, providing a high-resolution, in temporal and spatial scale, of information at individual level. Applications of these studies may be the definition of the home range of a target species, specifying the diel (Young, 1999; Belanger \& Rodriguez, 2001) and seasonal movements (Burrell et al., 2000), the influence of environmental factors (Ovídio et al., 1998) and the efficacy of fish pass programs (Scruton et al., 2002). Nevertheless, the high costs of individual tags and the detection equipment restrict the number of fishes utilized in the studies. Furthermore, the small-bodied fishes and fine scale movements are also other limitation that constrains the use of radiotelemetry (Prentice et al., 1990a; Lucas \& Baras, 2000). Alternatively, passive integrated transponder (PIT) technology was developed (Prentice et al., 1990b; BarbinZydlewski et al., 2001) for tracking even small aquatic animals in shallow waters, involving low equipment costs and the possibility of addressing numerous questions in fields of animal behaviour, habitat use and population dynamics (Roussel et al., 2000; Quintella et al., 2005). Besides, other advantages could be assigned to this technique, like the theoretically indefinite life span added to high tag retention and no apparent effects on growth and survival of tagged animals (Ombredane et al., 1998; Bubb et al., 2002). In addition, PIT telemetry equipment options (e.g. stationary versus portable detectors) were developed and applied with similar objectives of radiotelemetry technology, for example, the evaluation of fish pass efficiency (Prentice et al., 1990b; CastroSantos et al., 1996) or habitat use and behavioural studies of fish populations (Riley et al., 2003; Roussel et al., 2004).

The objective of the present study was to examine the comparative behaviour and habitat use of sympatric native and stocked brown trout in two streams of northeastern Portugal using PIT telemetry technology and multiple antennae. In detail, the detector system allowed continuous surveys on the movements, habitat use and activity pattern of both populations in two stream segments. PIT tags were selected because, besides having a comparatively low cost, their dimensions have a negligible effect on fish movements, which is a crucial aspect in fine-scale movements. Further, a comparison between PIT telemetry and a direct observation method (snorkelling) was also made.

\section{Materials and methods}

Study area

The experiments were carried out in the Baceiro and Sabor headwater streams (3rd order), tributaries of the River Douro basin, located in the Montesinho Natural Park, northeastern Portugal. These streams are subjected to a reduced human pressure, which contributes to the low impact on water composition (conductivity $<70 \mu \mathrm{S} \mathrm{cm}^{-1}$, alkalinity $<25 \mathrm{mg} \mathrm{HCO}_{3}^{-1} \mathrm{l}^{-1}$, hardness $<15 \mathrm{mg}$ $\mathrm{CaCO}_{3} \mathrm{l}^{-1}, \mathrm{NO}_{3}^{-}<0.50 \mathrm{mg} \mathrm{l}^{-1}, \mathrm{PO}_{4}^{3-}<0.02 \mathrm{mg} \mathrm{l}^{-1}$ ). Banks are covered by dense riparian vegetation dominated by alder (Alnus glutinosa, Gaertn), limiting the primary production in these systems where the food webs are energetically dependent on allochthonous inputs of organic matter. The fish community is dominated by native brown trout populations, but endemic cyprinid species are also present, such as the Iberian chub Squalius carolitertii (Doadrio, 1987) and the Iberian nase Chondrostoma duriensis Coelho, 1985.

\section{PIT telemetry equipment}

The PIT technology used was based on a multipoint decoder (MPD) unit (UKID Systems Ltd, Preston, U.K.). This unit consists of DC integrated MPD/antenna multiplexer (8-channel) powered by a $24 \mathrm{~V}$ (18 Ah) rechargeable leadacid battery pack, which provided more than $24 \mathrm{~h}$ of continuous use, and eight black circular panel antennae connected to the PIT-tag reader by cable lengths of $10 \mathrm{~m}$. Each panel antenna (22 $\mathrm{mm}$ deep and $300 \mathrm{~mm}$ in diameter) operates at a frequency of $134 \mathrm{kHz}$ and has a detection range of approximately $90 \mathrm{~mm}$ for the $12.0 \mathrm{~mm}$ long and $2.1 \mathrm{~mm}$ in diameter PIT tags (122IJ; 
UKID Systems) used in this study. This system enables logging up to 1000 time-stamped events from an onboard Real Time Clock and the Battery Backed-up Memory. In order to reduce the number of repetitive events, resulting from a fish that remained over the same antenna, a data repeated filter precluded the repeat reading of the same tag code within each $25 \mathrm{~s}$ period. The identification data (ID) output was further downloaded from the MPD (via RS232) to a personal computer. The battery pack and the MPD were protected by a special enclosure (Peli-Plastic equipment case).

\section{Field surveys}

Two representative stream segments $(30 \mathrm{~m}$ long by a mean width of $6 \mathrm{~m}$ ), with riffle and pool habitats, were selected in the Baceiro and Sabor streams. Aquatic habitat was assessed, before PIT telemetry experiments, based on transects (starting point randomly chosen), made perpendicular to the stream, with $5 \mathrm{~m}$ intervals throughout each stream segment. Point measurements were done at $0.5 \mathrm{~m}$ intervals across each transect for the variables of total depth, surface velocity (measured $10 \mathrm{~cm}$ below the surface), bottom velocity (10 $\mathrm{cm}$ above the streambed) and mean water column velocity (0.6 of total depth), substrate composition and cover. Substrate composition was classified according to a modified Wentworth scale, adopting the following categories: (1) organic detritus; (2) silt and sand $(<2 \mathrm{~mm})$; (3) gravel (2-16 mm); (4) pebble (17-64 mm); (5) cobble (65-256 mm); (6) boulder (>256 mm) and (7) bedrock. Cover types were divided into five categories: (1) objects $>15 \mathrm{~cm}$ (substrate emerging from the streambed); (2) overhanging vegetation; (3) roots, undercut banks and submerged woody debris; (4) surface turbulence and (5) no cover. Total depth was directly measured with a stick meter and the velocities were measured with a Valeport electronic flowmeter. For the available habitat surveyed, total depth was $56 \mathrm{~cm}$ $( \pm 0.08 \mathrm{SE}$; maximum depth $=110 \mathrm{~cm})$ in the Baceiro and $42 \mathrm{~cm}( \pm 0.15 \mathrm{SE}$; maximum depth $=$ $95 \mathrm{~cm}$ ) in the Sabor. Mean water column velocity was higher $\left(0.071 \pm 0.03 \mathrm{~m} \mathrm{~s}^{-1} \mathrm{SE}\right.$; maximum velocity (riffle) $-1.10 \mathrm{~m} \mathrm{~s}^{-1}$ ) in the Sabor than in the Baceiro $\left(0.041 \pm 0.09 \mathrm{~m} \mathrm{~s}^{-1} \mathrm{SE}\right.$ maximum velocity (riffle) $-0.90 \mathrm{~m} \mathrm{~s}^{-1}$ ). Substrate composition was dominated by pebbles and cobblestones in the Sabor and sand, cobblestones and boulders in the Baceiro streams. Overhanging vegetation, undercut banks and boulders were the main types of available cover for fish. During field experiments the water temperature displayed a low variation in both streams $\left(14-19^{\circ} \mathrm{C}\right.$ in the Baceiro and $13-18^{\circ} \mathrm{C}$ in the Sabor).

A total of 39 stocked and 32 native brown trout were marked with PIT-tags in the two experiments realized in the Baceiro and Sabor streams. Before the operation, each fish was individually anesthetized in a solution of 2-phenoxy-ethanol $\left(0.4 \mathrm{ml} \mathrm{l}^{-1}\right)$ and the abdominal region disinfected with an iodine solution (Betadine). The PIT-tag was surgically implanted in the peritoneal cavity with a sterilised needle linked to a special tagging gun. Stocked trout were tagged in the hatchery and held for eight days (at low density) in raceway tanks to recover from this operation. No tag loss or mortalities were registered during this period. Between 24 August and 9 September 2004, the entire study section in the Baceiro was closed with barrier nets until the end of the experiment, and the study area was sampled to depletion with several electrofishing sweeps (Hans Grassl DC, 1.5 W, 300/600 volts). Nineteen native trout (size range between 12.0 and $26.0 \mathrm{~cm}$ ), were captured and also anaesthetized, the total length measured $( \pm 1 \mathrm{~mm})$ and marked with the PIT-tags following the procedure mentioned above. After a recovery period of $2 \mathrm{~h}$, they were released, together with 26 stocked fishes (size range between 16.2 and $23.0 \mathrm{~cm}$ ), in the stream segment selected. Between 19 September and 4 October 2004 the same procedures were conducted along the segment selected in the Sabor. Here, the trout sample tagged consisted of 13 native (size range between 13.7 and $28.5 \mathrm{~cm}$ ) and 11 stocked trout (size range between 17.0 and $26.5 \mathrm{~cm})$.

The MPD unit and the eight panel antennae were installed in the streambed according to the diagram showed in Riley et al. (2003), although with a random antenna positions. Five sections (6 m long) were considered in the selected segment, since the maximum length of each cable 
(10 m) connecting the antenna to MPD unit limited the sampling, at the same time, of the whole study site. The experiments began systematically from the upstream to the downstream section, and each antenna was randomly positioned and every 3 days repositioned in a new section. Immediately after each antenna installation, the following microhabitat variables were recorded: total depth, dominant and subdominant substrate, surface, water column and bottom (near the antenna) velocities, aquatic cover, overhanging vegetation (shading), distance to riffle and distance to nearest stream bank. During study experiments the weather conditions remained quite stable (no substantial variations were detected for water level regimes) and the values of microhabitat measurements assumed constant for every 3-day period. In order to minimize the visual effect of the antennae on fish, they were covered, when possible, with a thin layer of the adjacent substrate and the first recording considered only $30 \mathrm{~min}$ (normal activity of fish re-established) after the perturbation promoted by the operator with the antennae repositioning and habitat measurements.

Habitat use by stocked and native trout was also studied, during September 2002, by snorkelling observations. This is a direct method usually employed in the evaluation of habitat use by fish in small streams (Thurow \& Schill, 1996). The stream segments (defined for telemetry experiments) were surveyed and the data observations distributed by 140 small native $(<20.0 \mathrm{~cm}), 26 \mathrm{big}$ native $(\geq 20.0 \mathrm{~cm})$ and 208 stocked trout to assess the microhabitat used. To the data collection a snorkeler moved systematically in upstream direction and after locating an undisturbed fish (only considered when maintaining a position for at least during $2 \mathrm{~min}$ ), the TL-total length (estimated to the nearest $\mathrm{cm}$ through comparison with substrate particles) and the trout identification (stocked versus native) were registered. Several characteristics allowed the snorkeler to correctly identify a stocked fish, such as the presence of VIE elastomer (Northwest Marine Technology ${ }^{\circledR}$ ) located in the adipose fin and post-ocular tissue, the body's color (uniform and gray) and the pectoral fins (smaller). Then, each fish position was marked with a numbered lead-weighted float (surface and focal position identified) and, after the whole stream segment was snorkeled, the measurements were made for the variables of focal velocity (velocity in the holding fish position), water column velocity (measured at 0.6 of total depth), surface velocity, focal elevation (vertical distance from bottom to fish's snout), total depth, dominant and subdominant substrate $(25 \times 25 \mathrm{~cm})$ in a vertical below the fish and cover (objects that could provide shelter for, at least, of $50 \%$ fish's body).

Data analyses

The statistical analyses were based on the information obtained in terms of repeated (all events recorded in the overall antennae by the different individuals) and non-repeated (the continuous repeated records of each fish in the same antenna were not considered) frequency data recording by de MPD unit during the sampling period in both streams.

Multivariate analyses techniques were applied to the PIT-telemetry data. A direct ordination technique-canonical correspondence analysis (CCA), was performed for both streams through the CANOCO software package (Version 4.02, Ter Braak \& Smilauer, 1998) to evaluate the links between environmental variables and microhabitat used by fish. Data were standardized for microhabitat variables and logged transformed $[\log (x+1)]$ for the non-repeated frequency of the detected fish in all antennae positions. Only those variables with a variation inflation factor (VIF) of less than 20 were included to avoid multicollinearity (Ter Braak, 1986). In addition, a Monte Carlo permutation test (199 permutations) was performed to test the significance of stocked and native trout and the environmental variables.

A classification tree analysis was used to predict the membership of cases in the three classes of a categorical dependent variable, defined as: (1) stocked (age 1+ and mean size of $18.0 \mathrm{~cm}$ ); (2) small native $<20.0 \mathrm{~cm}$ and big native $\geq 20.0 \mathrm{~cm}$ trout, from the following predictor variables: maximum values of water column velocity, cover, distance to streambank, both maximum and minimum values of depth, dominant substrate and distance to riffle. These 
variables were selected after being eliminated those with low variance. Fish without registered occurrences, at least, in three distinct antennae were not included in this analysis in order to eliminate the outlier data resulting from fish detected only in the first days. The classification tree performed was based on discriminant univariate splits, considering estimated prior probabilities, equal misclassification costs and a FACT-style direct stopping with fraction of objects of 0.30 . This is an exploratory technique known for its flexibility to examine the effects of the predictor variables one at a time, which display a graphic presentation of easy interpretation. However, when more stringent theoretical and distributional assumptions are met, traditional methods may be preferable (Breiman et al., 1984). In this way, another multivariate technique was carried out-Discriminant Function Analysis (DFA), with a statistical base similar to the classification tree, for the same variables and fish groups (stocked, small and big native trout) considering a forward stepwise analysis. Analogous analysis (DFA) was also applied to direct observation data, taking in account the same trout classes pre-defined in order to find the variables with the most discrimination power and to establish comparisons between both methods (PIT telemetry versus snorkelling).

Trout activity was analysed considering intervals of $3 \mathrm{~h}$ and the antennae non-repeated frequency records and, subsequently, polynomial regressions were fitted to the data. Differences among all trout classes for the microhabitat variables defined were assessed using Kruskall-Wallis $\mathrm{H}$-tests because data did not fit to the assumptions of normality (Bartlet test). All statistical analyses were performed using STATISTICA 7.0 package (STATSOFT, 2004).

\section{Results}

A total of 19,326 fish records (tag codes) were successfully registered by the MPD unit in the experiments realized in both streams, and only $0.07 \%$ corresponded to unidentified tag codes. From 71 PIT-tagged fishes, 76.9\% (30 individuals) of stocked and 59.4\% (19 individuals) of native trout were detected at least once by the reader unit. Comparatively, a higher number of fish detections were obtained in the Sabor than in the Baceiro (84.6 vs. $73.1 \%$ for stocked and 76.9 vs. $47.4 \%$ for native trout). Dominant native trout showed a higher activity (based on the frequency of the recordings) during the dawn period (6.01$9.00 \mathrm{~h}$ ) in both streams. Small native trout had similar behaviour to big native trout in the Baceiro, but avoided the same period in the Sabor, probably related to the greater mobility exhibited by bigger native and stocked trout found in the major activity in the evening. No apparent reasons justify the distinct stocked trout behaviour detected between the two streams (Figs. 1, 2). Stocked fishes displayed greater mobility than native trout, since a higher frequency was observed (66.3\% for total events and $68 \%$ for non-repeated events).

Habitat use by stocked and native trout differed markedly for the majority of variables considered (Table 1). Total depth observed by small and big native trout was significantly lower than the total depth used by stocked fish in both streams $(P<0.001, \mathrm{H}$ test $)$. Similarly, the velocities measured at the three vertical levels were significantly higher for the big native trout than for small native and stocked trout, in both streams $(P<0.05, \mathrm{H}$ test $)$. Bigger native trout more often used the upstream area closest to the riffle, meanwhile stocked trout were located in the middle of the channel, since, comparatively with native trout, they occupied habitats significantly more distant from the stream bank $(P<0.05, \mathrm{H}$ test). For hatchery-reared fish the aquatic cover provided by undercut banks and roots was, in both streams, the category type less used. We must mention that an important proportion of stocked fish remained in areas without any type of cover. Conversely, the habitat used by the dominant native trout displayed a preference for coarse particles (pebbles, cobblestones and boulders). Meanwhile for small native trout the undercut banks and the overhanging vegetation (especially in the Sabor) was also another elected shelter type. The links between the microhabitat variables and stocked and native trout for both streams are shown in the CCA ordinations (Figs. 3, 4). The first two CCA axes had eigenvalues of 0.750 and 0.314 for the Baceiro and 
Fig. 1 Activity pattern, using polynomial regressions, performed for stocked $(n=527)$, small native $(n=148)$ and big native trout $(n=215)$ relative to eight diel periods and 3-h classes, in the Baceiro stream. The dependent variable represents the relative probability of use (standardized to a 0-1 scale). Stocked trout are represented by a solid line, big native trout by a dashed line and small native trout by a dotted line

Fig. 2 Activity pattern, using polynomial regressions, performed for stocked $(n=585)$, small native $(n=88)$ and big native trout $(n=72)$ relative to eight diel periods and 3-h classes, in the Sabor stream. The dependent variable represents the relative probability of use (standardized to a 0-1 scale). Stocked trout are represented by a solid line, big native trout by a dashed line and small native trout by a dotted line
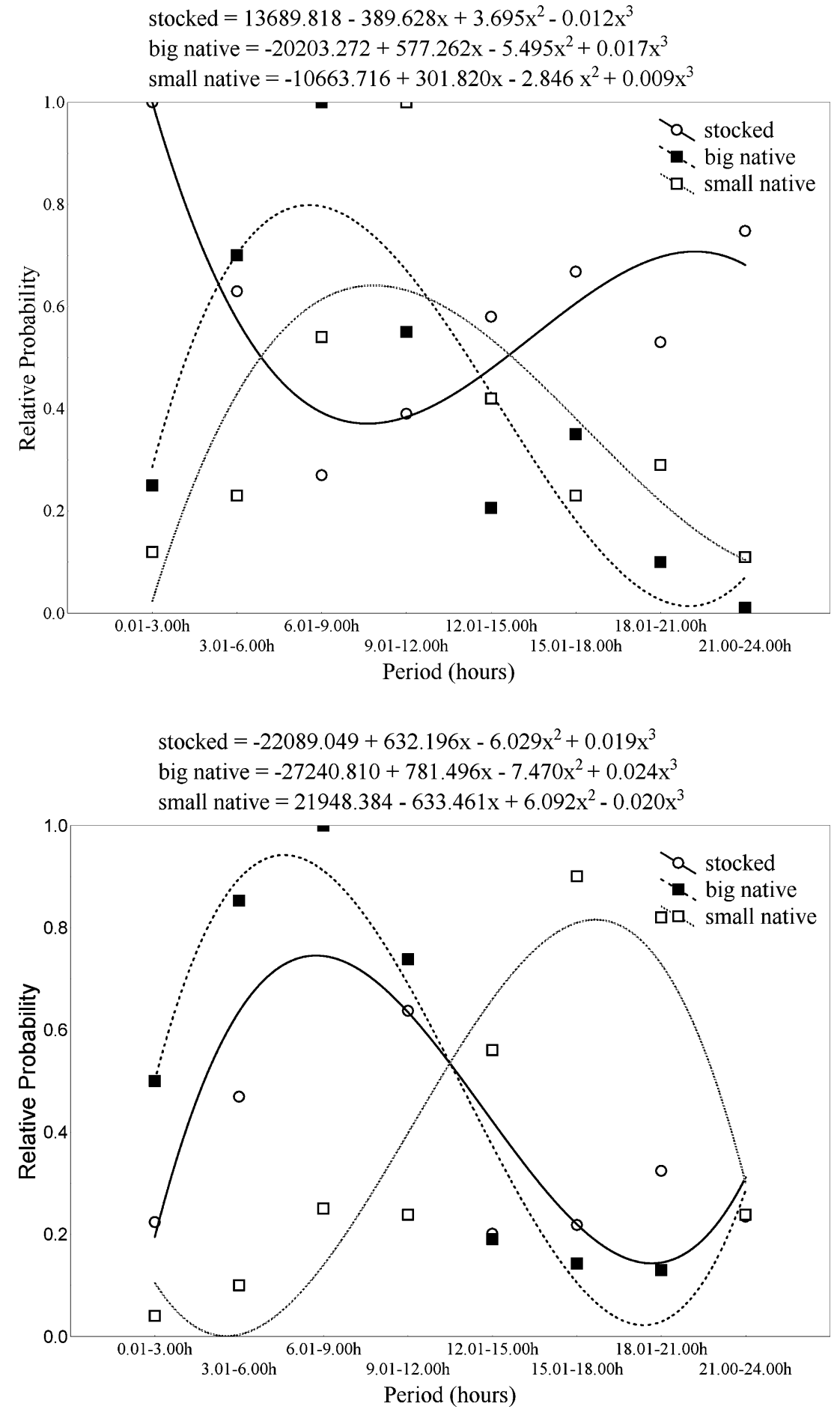

0.298 and 0.224 for the Sabor, explaining together, respectively, $65.2 \%$ and $53.7 \%$ of variation in the relationship between native and stocked trout and environmental variables
(Table 2). Furthermore, the overall Monte Carlo randomization tests showed significant results for the sum of all eigenvalues (199 permutations, $P<0.05)$. The environmental variables most 
Table 1 Mean $( \pm 1$ S.E.) total depth $(\mathrm{cm})$, distance to nearest stream bank $(\mathrm{cm})$, distance to riffle $(\mathrm{cm})$ surface velocity $\left(\mathrm{m} \mathrm{s}^{-1}\right)$, water column velocity $\left(\mathrm{m} \mathrm{s}^{-1}\right)$ and bottom velocity $\left(\mathrm{m} \mathrm{s}^{-1}\right)$ from the 40 antennae positions of small native, big native and stocked trout in the Baceiro and Sabor streams

\begin{tabular}{|c|c|c|c|c|c|c|}
\hline \multirow[t]{2}{*}{ Microhabitat variables } & \multicolumn{3}{|l|}{ Baceiro stream } & \multicolumn{3}{|l|}{ Sabor stream } \\
\hline & $\begin{array}{l}\text { Small native } \\
(n=178)\end{array}$ & $\begin{array}{l}\text { Big native } \\
(n=185)\end{array}$ & $\begin{array}{l}\text { Stocked } \\
(n=527)\end{array}$ & $\begin{array}{l}\text { Small native } \\
(n=18)\end{array}$ & $\begin{array}{l}\text { Big native } \\
(n=142)\end{array}$ & $\begin{array}{l}\text { Stocked } \\
(n=585)\end{array}$ \\
\hline Total depth & $56.0 \pm 1.16$ & $59.2 \pm 1.75$ & $65.9 \pm 0.98$ & $34.6 \pm 2.88$ & $34.3 \pm 1.22$ & $62.3 \pm 1.19$ \\
\hline Distance to stream bank & $93.0 \pm 9.51$ & $100.7 \pm 5.51$ & $117.8 \pm 4.40$ & $58.4 \pm 12.12$ & $83.6 \pm 8.53$ & $211.7 \pm 6.05$ \\
\hline Distance to riffle & $1393.6 \pm 64.23$ & $314.2 \pm 10.28$ & $445.5 \pm 18.59$ & $1477.2 \pm 142.9$ & $648.9 \pm 46.98$ & $1236.1 \pm 32.94$ \\
\hline Surface velocity & $0.017 \pm 0.003$ & $0.073 \pm 0.004$ & $0.065 \pm 0.003$ & $0.055 \pm 0.030$ & $0.223 \pm 0.02$ & $0.123 \pm 0.01$ \\
\hline Water column velocity & $0.014 \pm 0.003$ & $0.077 \pm 0.004$ & $0.057 \pm 0.003$ & $0.044 \pm 0.024$ & $0.165 \pm 0.01$ & $0.083 \pm 0.01$ \\
\hline Bottom velocity & $0.014 \pm 0.003$ & $0.088 \pm 0.006$ & $0.056 \pm 0.003$ & $0.034 \pm 0.020$ & $0.134 \pm 0.01$ & $0.057 \pm 0.01$ \\
\hline \multicolumn{7}{|l|}{ Dominant substrate } \\
\hline Organic detritus & 21.5 & 4.9 & 18.0 & 0.0 & 0.0 & 0.0 \\
\hline Silt and sand & 0.6 & 0.0 & 10.2 & 0.0 & 0.0 & 0.0 \\
\hline Gravel & 28.1 & 9.2 & 6.3 & 33.3 & 2.8 & 23.6 \\
\hline Pebble & 5.6 & 31.4 & 19.7 & 38.8 & 3.5 & 2.1 \\
\hline Cobble & 21.2 & 43.2 & 27.8 & 5.6 & 41.5 & 13.2 \\
\hline Boulder & 9.0 & 11.3 & 17.3 & 16.7 & 41.5 & 53.3 \\
\hline Bedrock & 14.0 & 0.0 & 0.8 & 5.6 & 10.7 & 7.8 \\
\hline \multicolumn{7}{|l|}{ Aquatic cover } \\
\hline $\begin{array}{l}\text { Substrate particles } \\
\qquad(>15 \mathrm{~cm})\end{array}$ & 60.7 & 64.3 & 35.1 & 11.1 & 45.8 & 28.4 \\
\hline Overhanging vegetation & 7.3 & 3.2 & 5.3 & 44.4 & 12.0 & 13.2 \\
\hline $\begin{array}{l}\text { Roots, undercut banks, } \\
\text { woody debris }\end{array}$ & 10.7 & 0.5 & 0.4 & 38.9 & 12.7 & 0.7 \\
\hline Surface turbulence & 2.8 & 17.8 & 16.7 & 0.0 & 3.5 & 6.0 \\
\hline No cover & 18.5 & 14.1 & 42.5 & 5.6 & 26.1 & 51.8 \\
\hline
\end{tabular}

Cover and dominant substrate type used by fishes are shown as relative frequency (\%). Numbers of observations $(n)$ are presented in parentheses and correspond to non-repeated frequency data for each trout class

important in the stocked and native trout distribution among antennae sites were the distance to riffle and the distance to nearest stream bank for both streams and subdominant substrate (Baceiro), total depth and overhanging vegetation (Sabor) (Table 3, Figs. 3, 4).

The classification tree diagram is shown on Fig. 5. Initially the 36 trout considered are assigned to the root node (node 1, top-left corner) classified as stocked (top-right corner) because there is a prevalence of stocked (23 individuals) compared to native trout (small-7 and big-6 individuals). Two new nodes (nodes 2 and 3 ) were formed by the split of the root node. The computational method selected the maximum depth as the predictor variable that produced the smallest $P$-level and the cluster analysis (2means) defined the separation value of $86.5 \mathrm{~cm}$ between nodes. Similarly, subsequent node splits were successively made and different predictor variables were selected (maximum cover, minimum and maximum depths). In the end, five splits and six terminal nodes allowed the separation between stocked and native trout. Just one terminal node (node 8) reached "pure" classification; nevertheless, the percentage of objects misclassified was 16.7. Additionally, the discriminant-based univariate split option allowed for the identification of the main predictor variables. The best rankings (0-100 scale) were obtained by the following variables: maximum depth (rank 100), maximum distance to riffle (rank 69) and minimum dominant substrate (rank 62).

In addition, another multivariate technique, DFA was applied to these data, considering the same nine variables and the predefined trout groups. The results, confirmed that the maximum depth was the variable that most contributed to the separation between stocked, small and big native trout (Table 4). However, all stocked trouts were correctly classified $(100 \%)$, unlike the big $(33.3 \%)$ and the small $(14.3 \%)$ native 


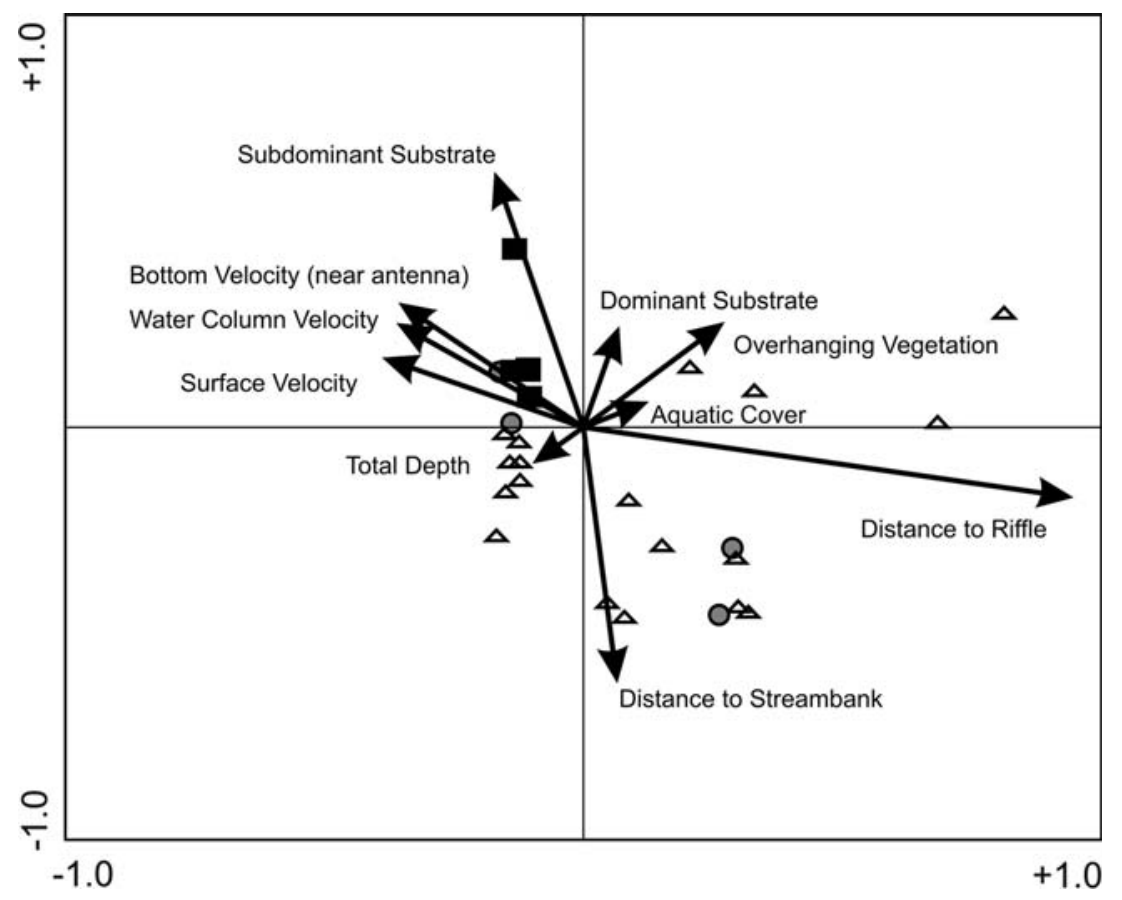

Fig. 3 CCA ordination diagram-Baceiro stream: distribution of native and stocked trout according to the selected microhabitat variables for the two first axes. The arrows represent the microhabitat variables and the symbols are the trout identification: (A) arrows-total depth; aquatic cover; overhanging vegetation; surface,

trout. The total percentage of corrected cases obtained by the DFA (72.2\%) was lower when compared with classification tree analysis $(83.3 \%)$, which is more flexible. The scatterplot of the two principal roots (Fig. 6) exhibits, in fact, a less clear separation between the groups. Table 4 presents the summary output of DFA analysis, where no significant functions (canonical roots) were found.

Finally, when this analysis (DFA) was applied to direct observational data (i.e. snorkelling), focal elevation, was identified as one of the most important variables in the discrimination detected between the predefined groups (Table 5). In fact, stocked trout occupied water column positions (focal elevations) more distant from the streambed when compared with native trout. In the DFA analysis two significant functions were calculated and an evident separation between stocked and native trout can be shown along the root 1 (Fig. 7). Besides, comparatively with DFA water column, and bottom (near antenna) velocities; distance to riffle; distance to the nearest streambank; (B) Symbols: $\bigcirc=$ small native; $\boldsymbol{\square}=$ big native; $\Delta=$ stocked trout. The length of the arrow is a measure of the importance of the environmental variable and the arrowhead points at the direction of increasing influence

made with PIT telemetry data, a superior percentage (94.1) of corrected cases was detected (Table 5).

\section{Discussion}

Distinct habitat use was identified for the stocked and the two native trout classes by PIT-telemetry. These results corroborate the direct observations (snorkelling) that took place in the same streams considering the two sympatric populations mentioned. Multivariate analyses (CCA, DFA and classification tree) performed with data collected by both methods (PIT-telemetry and snorkel observations) found the total depth and the aquatic cover as being important microhabitat variables that contributed to the separation of predetermined groups. Despite this, some important differences between both methods were registered, resulting from the limitations assigned 


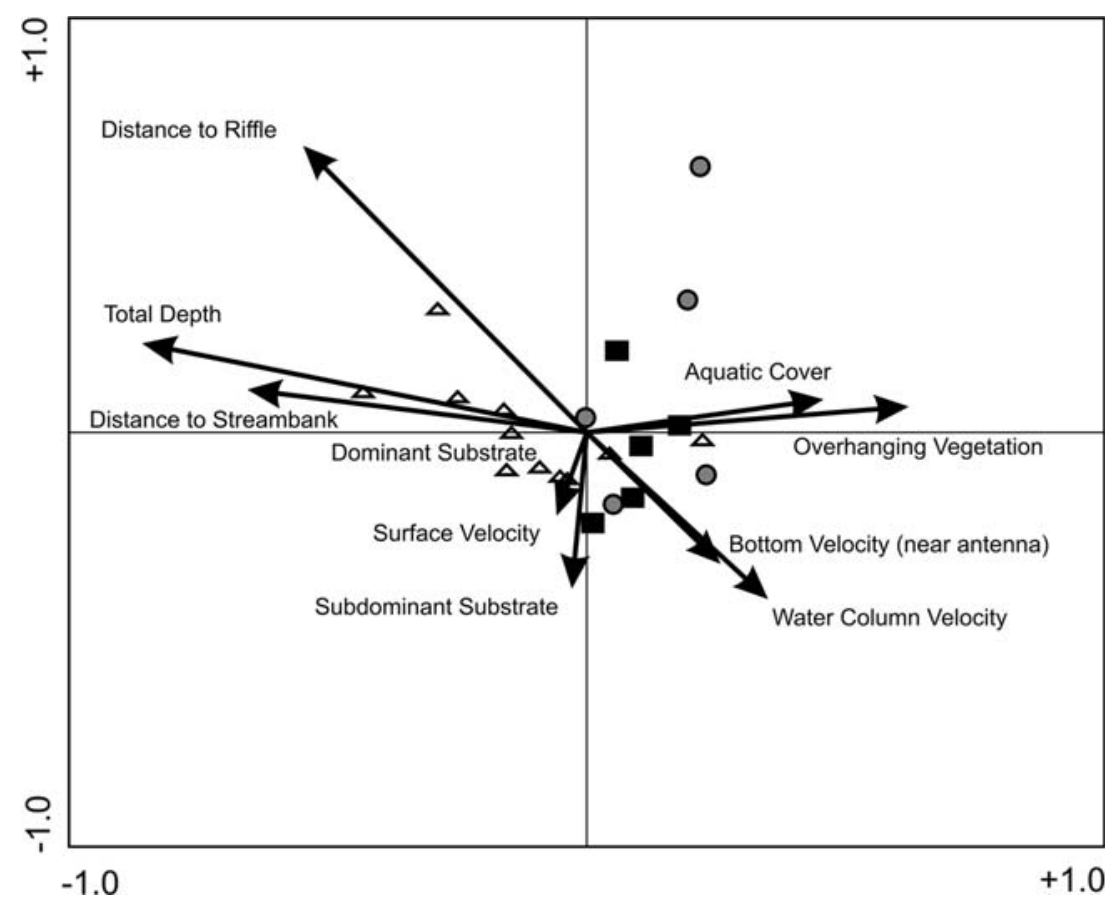

Fig. 4 CCA ordination diagram-Sabor stream: distribution of native and stocked trout according to the selected microhabitat variables for the two first axes. The arrows represent the microhabitat variables and the symbols are the trout identification: (A) arrows - total depth; aquatic cover; overhanging vegetation; surface, water column, and bottom (near antenna) velocities; distance to riffle; distance to the nearest streambank; (B) Symbols: $\mathrm{O}=$ small native; $\mathbf{\square}=$ big native; $\Delta=$ stocked trout. The length of the arrow is a measure of the importance of the environmental variable and the arrowhead points at the direction of increasing influence

Table 2 Summary of the canonical correspondence analysis (CCA) for Baceiro and Sabor streams

\begin{tabular}{|c|c|c|c|c|c|c|}
\hline & \multicolumn{3}{|c|}{ Baceiro stream } & \multicolumn{3}{|c|}{ Sabor stream } \\
\hline & Axis 1 & Axis 2 & Total inertia & Axis 1 & Axis 2 & Total inertia \\
\hline Eigenvalues & 0.750 & 0.314 & 4.090 & 0.298 & 0.224 & 2.900 \\
\hline Species-environment correlations & 0.963 & 0.816 & & 0.792 & 0.748 & \\
\hline $\begin{array}{l}\text { Cumulative percentage variance } \\
\text { of species data } \\
\text { of species-environment relations }\end{array}$ & $\begin{array}{l}18.4 \\
46.0\end{array}$ & $\begin{array}{l}26.0 \\
65.2\end{array}$ & & $\begin{array}{l}10.3 \\
30.6\end{array}$ & $\begin{array}{l}18.0 \\
53.7\end{array}$ & \\
\hline Sum of all canonical eigenvalues & & & 1.633 & & & 0.973 \\
\hline
\end{tabular}

Monte Carlo permutation tests run for the sum of all eigenvalues were significant (199 permutations, $P=0.005$ for Baceiro stream and $P=0.015$ for Sabor stream)

to each method. For example, the focal elevation (vertical distance of fish position to the bottom of the stream) was the most discriminant microhabitat variable in underwater observation method, but can not be considered in the PIT-telemetry method applied in this study, since the detection range of each panel antenna is approximately $90 \mathrm{~mm}$ for the PIT-tags used (12.0 mm long). For this reason, biased data could be related to the efficiency of detection especially when the fish holds a position, or swims, just above an antenna and over the detection range. It is important to mention that in this study a considerable area is out of the detection range of the PIT antennae and underestimate data were obtained essentially by stocked trout. Indeed, it was observed during 
Table 3 Interset-correlations (Pearson correlation coefficient) of environmental variables with the CCA axes for Baceiro and Sabor streams

\begin{tabular}{llccc}
\hline Environmental variables & \multicolumn{2}{l}{ Baceiro stream } & & \multicolumn{2}{c}{ Sabor stream } \\
\cline { 2 - 3 } & Axis 1 & Axis 2 & Axis 1 & -0.156 \\
\hline Total depth & -0.092 & -0.063 & $-0.681^{* *}$ & -0.155 \\
Surface velocity & $-0.373^{*}$ & 0.135 & -0.049 & $-0.304^{*}$ \\
Water column velocity & $-0.349^{*}$ & 0.211 & 0.278 & -0.240 \\
Bottom (antenna) velocity & $-0.340^{*}$ & 0.249 & 0.207 & -0.091 \\
Dominant substrate & 0.066 & 0.201 & 0.004 & -0.286 \\
Subdominant substrate & -0.164 & $0.507^{* *}$ & -0.024 & 0.054 \\
Aquatic cover & 0.116 & 0.049 & $-0.361^{*}$ & 0.075 \\
Distance to nearest streambank & 0.061 & $-0.503^{* *}$ & $-0.520^{* *}$ & $0.515^{* *}$ \\
Distance to riffle & $0.908^{* *}$ & -0.137 & $-0.433^{* *}$ & 0.046 \\
Overhanging vegetation & 0.257 & 0.210 & & $0.491^{* *}$ \\
\hline
\end{tabular}

$* P<0.05, * * P<0.01$

the snorkelling survey that native trout normally stay close to the streambed, except in particular moments like the feeding activity, in contrast with the behaviour displayed by stocked trout, which often occupy higher focal elevations (superficial and middle water column positions).

Similarly to other studies (Heggenes 1988; Rincón \& Lobón-Cerviá, 1993; Maki-Petays et al., 2002) where different sampling methods (e.g. snorkelling, electrofishing, seining) were used, PIT-telemetry proved to be an effective method to study the habitat requirements of fish populations. However, all methods present different limitations (Heggenes et al., 1990; Dolloff et al., 1996; Joyce \& Hubert, 2003). Generally, the main limitations cited for PIT-telemetry in field surveys are the stream depth (this method is more adapted to shallow streams), antenna range detection, species behaviour and the alterations promoted in the substrate composition due to the installation of the antenna (Riley et al., 2003; Cucherousset et al., 2005). On the other hand,

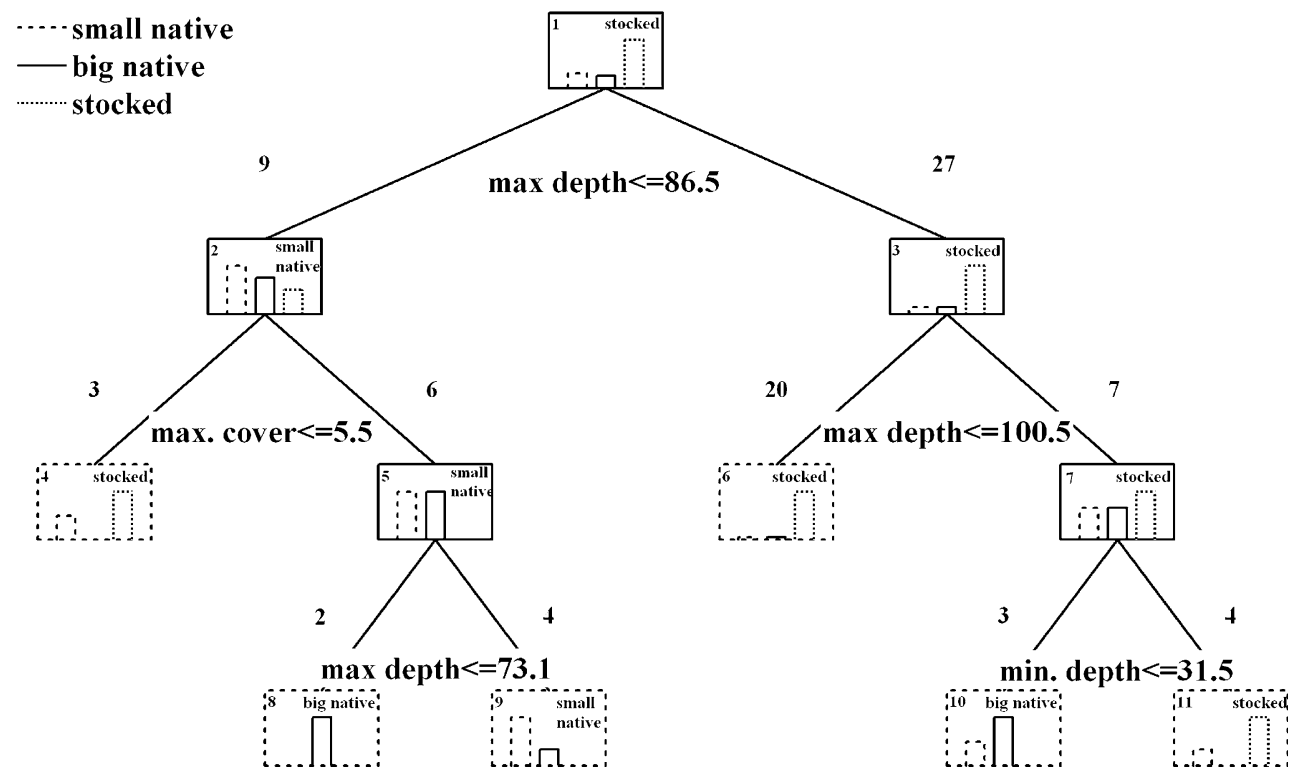

Fig. 5 Classification Tree-Tree structure graph for small native, big native and stocked trout. Five splits and six terminal nodes were found, at the end, with a global misclassification of $16.7 \%$. Non-repeated frequency data

$(n=1635)$ of 36 trout were used in this analysis excluding all fishes without, at least, recorded events on three different antennae. Terminal nodes are outlined with dashed lines 
Table 4 Discriminant function analysis (DFA) summary applied to PIT-telemetry data-Partial Wilks' Lambda for each variable and the classification functions according to different trout classes (small native, big native and stocked trout)

\begin{tabular}{|c|c|c|c|c|}
\hline \multicolumn{5}{|c|}{ Discriminant function analysis } \\
\hline \multirow{2}{*}{$\begin{array}{l}n=1635 \\
\text { Variables }\end{array}$} & \multirow{2}{*}{$\begin{array}{l}\text { Wilks' } \\
\text { lambda }\end{array}$} & \multicolumn{3}{|c|}{ Classification functions } \\
\hline & & $\begin{array}{l}\text { Small native } \\
P=0.194\end{array}$ & $\begin{array}{l}\text { Big native } \\
P=0.167\end{array}$ & $\begin{array}{l}\text { Stocked } \\
P=0.639\end{array}$ \\
\hline Maximum depth & 0.701 & -0.231 & -0.734 & 0.262 \\
\hline Max. water col. velocity & 0.666 & 0.384 & -0.260 & -0.050 \\
\hline Max. dominant substrate & 0.695 & 0.475 & -0.796 & 0.063 \\
\hline Maximum cover & 0.715 & -0.333 & 1.007 & -0.161 \\
\hline Max. distance to bank & 0.661 & -0.060 & -0.087 & 0.041 \\
\hline Max. distance to riffle & 0.665 & -0.233 & 0.203 & 0.018 \\
\hline Minimum depth & 0.701 & 0.809 & -0.460 & -0.126 \\
\hline Min. dominant substrate & 0.704 & -0.600 & 0.730 & -0.008 \\
\hline Min. distance to riffle & 0.663 & -0.001 & -0.300 & 0.078 \\
\hline Constant & - & -1.933 & -2.607 & -0.487 \\
\hline $\begin{array}{l}\text { Predicted classifications } \\
\text { (\% corrected cases })\end{array}$ & & 14.3 & 33.3 & 100 \\
\hline
\end{tabular}

Variables are listed in the order in which they were included in forward stepwise analysis

several advantages are linked to this method, such as the continuous remote monitoring even of small pit-tagged fishes with high spatial and temporal resolution and a minimum disturbance of aquatic environment, when compared, for example, with direct methods. In addition, the shallow and fast flowing riffle areas, impossible to sample with underwater observation, are easily surveyed through the PIT-telemetry (Riley et al., 2003). Finally, many researchers emphasize the
Fig. 6 Discriminant multivariate ordination (DFA) of predefined groups (classes are indicated by symbols: = small native; $\mathbf{\square}=$ big native; $\Delta=$ stocked trout), considering the PIT-Telemetry data $(n=1635)$ for both stream segments-Scatterplot of the first two canonical roots

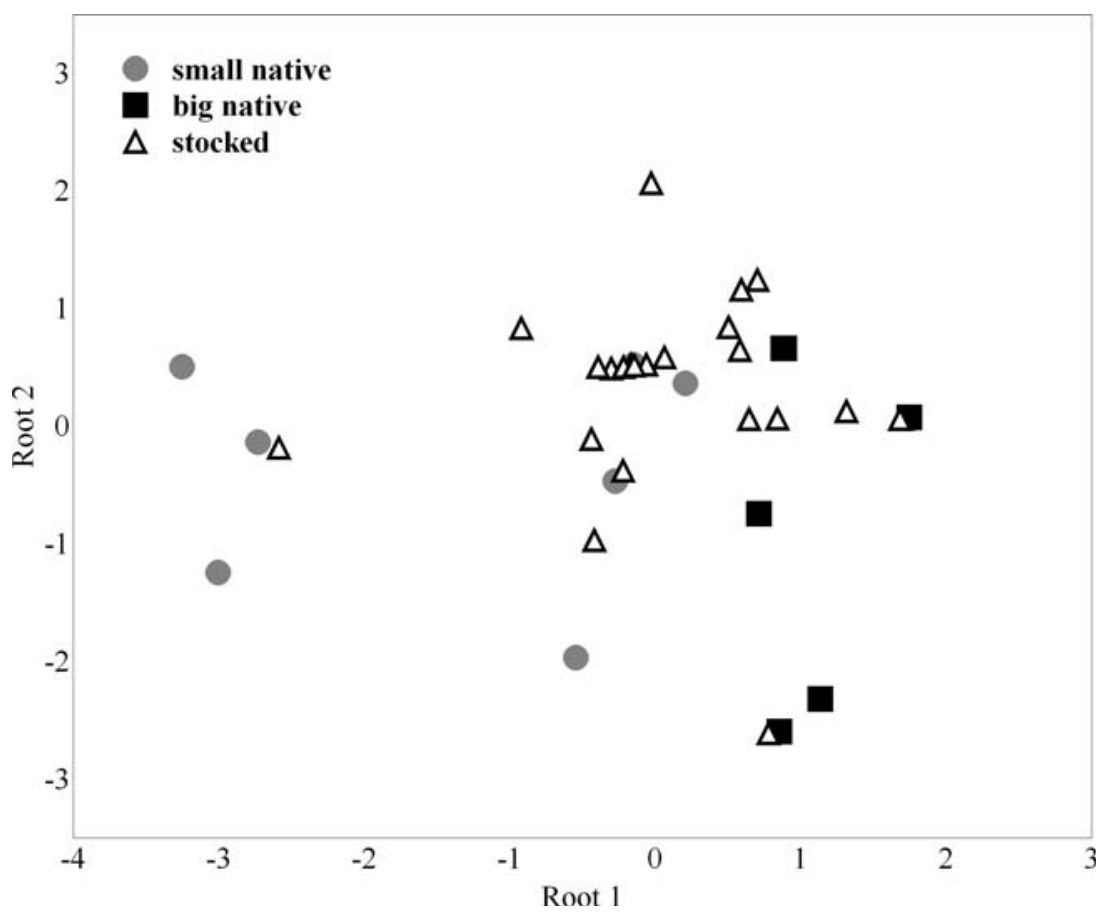


Table 5 Discriminant function analysis (DFA) summary applied to underwater observation data-Partial Wilks' lambda for each variable and the classification functions according to different trout classes (small native, big native and stocked trout)

\begin{tabular}{|c|c|c|c|c|}
\hline \multicolumn{5}{|c|}{ Discriminant function analysis } \\
\hline \multirow{2}{*}{$\begin{array}{l}n=374 \\
\text { Variables }\end{array}$} & \multirow[t]{2}{*}{ Wilks' lambda } & \multicolumn{3}{|c|}{ Classification functions } \\
\hline & & $\begin{array}{l}\text { Small native } \\
P=0.409\end{array}$ & $\begin{array}{l}\text { Big native } \\
P=0.035\end{array}$ & $\begin{array}{l}\text { Stocked } \\
P=0.556\end{array}$ \\
\hline Focal elevation & 0.671 & -1.198 & -1.241 & 0.959 \\
\hline Total depth & 0.501 & -0.447 & 0.838 & 0.276 \\
\hline Subdominant substrate & 0.485 & 0.298 & 0.410 & -0.245 \\
\hline Aquatic cover & 0.481 & 0.066 & 0.897 & -0.104 \\
\hline Dominant substrate & 0.480 & -0.245 & 0.001 & 0.180 \\
\hline Surface velocity & 0.476 & 3.391 & -0.607 & -2.456 \\
\hline Water column velocity & 0.475 & -3.171 & 0.570 & 2.297 \\
\hline Constant & - & -1.558 & -4.370 & -0.993 \\
\hline (\% corrected cases) & - & 94 & 0 & 82.7 \\
\hline
\end{tabular}

Variables are listed in the order in which they were included in forward stepwise analysis

PIT-tagging system's very efficient monitoring of the fish movements and its relative low costs (Castro Santos et al., 1996).

A greater proportion of stocked trout were detected in the different antennae of PITtelemetry system, confirming the high mobility displayed by these fishes and suggesting the lack of a capacity to define a territory and a specific resting area, usually found in wild salmonid species (Fausch, 1984). Certainly, the erratic swimming activity and the shoaling behaviour, more visible in the first days after their release in

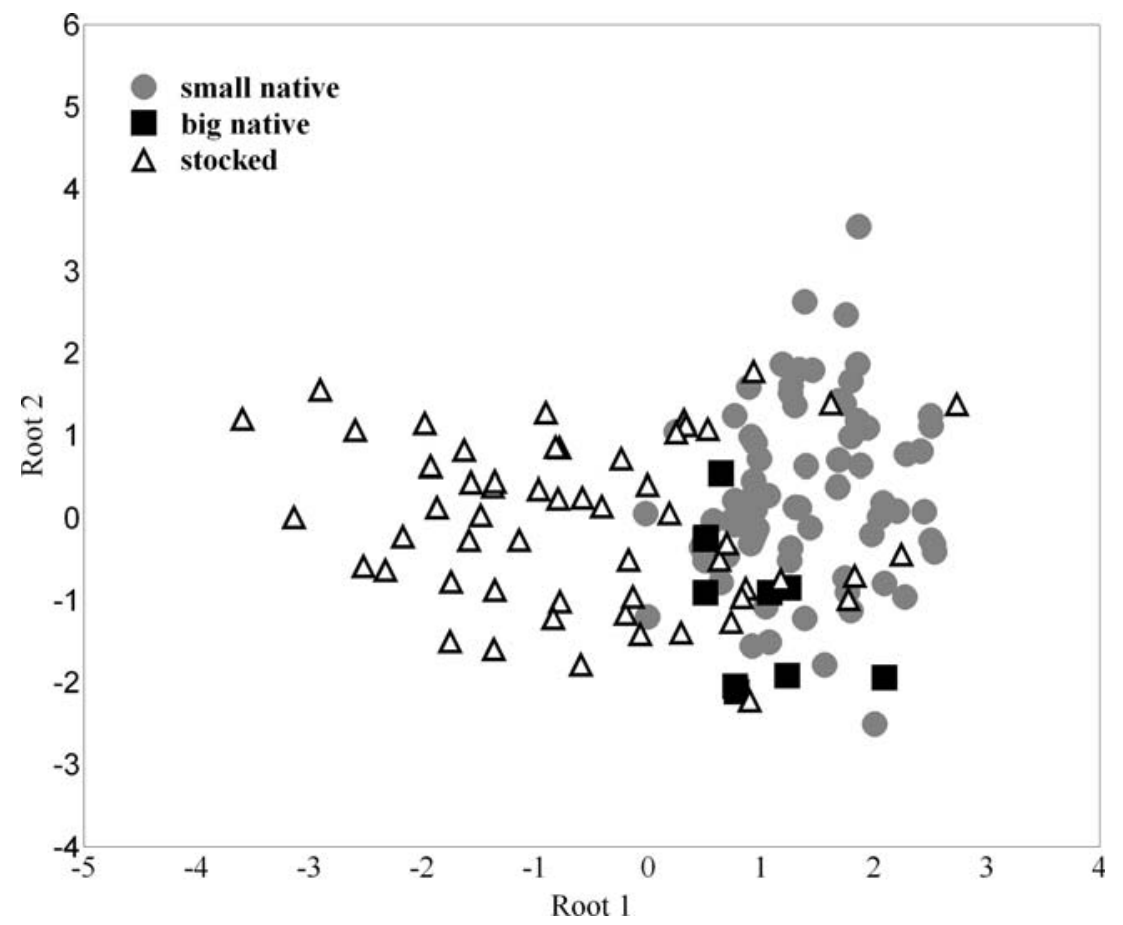

Fig. 7 Discriminant multivariate ordination (DFA) of predefined groups (classes are indicated by symbols:

considering the underwater observation method applied = small native; $\mathbf{\square}=$ big native; $\Delta=$ stocked trout), for both stream segments $(n=374)$-Scatterplot of the first two canonical roots 
the stream, are related to this behaviour. The high densities and the feeding regimes that promote a scramble-for-food environment are habits acquired by fish in hatcheries and contribute to suppress the establishment of social hierarchies that commonly occur in wild salmonid populations (Steward \& Bjornn, 1990). For these reasons, aggressive behaviour and more intense agonistic encounters were associated by many researchers with stocking activity (Mesa, 1991; Deverill et al., 1999). An immediate consequence is the displacement from energetically profitable positions of the wild fish, leading to a negative impact on growth and survival of the natural populations (Weber \& Fausch, 2005). However, our study detected a temporal (distinct maximum activity periods were observed, except for big native trout in the Sabor) and spatial segregation (significant differences were detected for the habitat used) between stocked and native trout, suggesting resource partitioning and probably, a distinct behaviour between the sympatric trout populations. Furthermore, the habitat used by dominant fishes (big native class) also differed from the small native ones. Comparatively, bigger trout were located, more often, by the PIT system in areas that provided refuge (resting activity), considering the aquatic cover and overhanging vegetation variables, near the upstream section (riffle area), normally associated with superior invertebrate drift rates. Indeed, the dominance in salmonids are linked to the profitable feeding areas and related to visible benefits in terms of survival and growth (Fausch, 1984). It is important to mention that, despite the presence of stocked trout, similar mean values for the variables of water column velocity $\left(<0.30 \mathrm{~m} \mathrm{~s}^{-1}\right.$, Rincón \& Lobón-Cerviá, 1993; Vismara et al., 2001) and depth (20-60 cm, Horton \& Cochnauer, 1978; Roussel et al., 1999) were found by other studies related to habitat used by native trout, in spite of a wide range of values being referred to in the bibliography (Bunt et al., 1999; Heggenes, 1988; Vismara et al., 2001). All comparisons of habitat used by PIT-tagged fishes with literature data must be, however, carefully analysed taking into account not only the different stream characteristics, namely the habitat availability, but also the limitations of each survey method utilized.
The knowledge of the ecological processes that regulate these aquatic systems will be essential to define the best management strategies of trout populations in Portuguese salmonid streams. In conclusion, the detailed information obtained with PIT-telemetry allowed us to consider this technology as a useful alternative, in low order streams, to several methods currently available in the study of behaviour and habitat use by fishes. However, further research is needed for a better understanding of the stocked and native trout behaviour in the study area. Experimental designs with this type of equipment must be applied in shallower habitats (riffle zones) and bigger PIT tags (e.g. 23-34 mm long) should be used to improve the detection range. Moreover, an extended field survey is essential to define the adaptation period and survival of stocked fish.

Acknowledgements We would like to thank Jorge Bochechas (Direcção Geral de Recursos Florestais), who made possible this collaboration, Vitor Rego, Julieta Sampaio (Circunscrição Florestal do Norte) and Graça Barreira (Serviços Florestais-Núcleo de Bragança) who provided all the conditions in the fishfarms, and Tiago Martins and Paula Escalda for their assistance on field work. Ray Vogensen provided helpful suggestions, which led to linguistic improvements of this manuscript.

\section{References}

Barbin-Zydlewski, G., A. Haro, K. G. Whalen \& S. D. McCormick, 2001. Performance of stationary and portable passive transponder detection systems for monitoring of fish movements. Journal of Fish Biology 58: 1471-1475.

Belanger, G. \& M. A. Rodriguez, 2001. Homing behaviour of stream-dwelling brook charr following experimental displacement. Journal of Fish Biology 59: 987-1001.

Breiman, L., J. H. Friedman, R. A. Olshen \& C. J. Stone, 1984. Classification and regression trees. Wadsworth \& Brooks/Cole Advanced Books \& Software. Monterey, CA.

Bridger, C. J. \& R. K. Booth, 2003. The effects of biotelemetry transmitter. Presence and attachment procedures on fish physiology and behavior. Reviews in Fisheries Science 11: 13-34.

Bubb, D. H., M. C. Lucas, T. J. Thom \& P. Rycroft, 2002. The potential use of PIT telemetry for identifying and tracking crayfish in their natural environment. Hydrobiologia 483: 225-230.

Bunt, C. M., S. J. Cooke, C. Katopodis \& R. S. McKinley, 1999. Movement and summer habitat of brown trout (Salmo trutta) below a pulsed discharge hydroelectric 
generating station. Regulated Rivers: Research and Management 15: 395-403.

Burrell, K. H., J. J. Isely, D. B. Bunnell Jr, D. H. Van Lear \& C. A. Dolloff, 2000. Seasonal movement of brown trout in a Southern Appalachian River. Transactions of the American Fisheries Society 129: 1373-1379.

Castro-Santos, T., A. Haro \& S. Walk, 1996. A passive integrated transponder (PIT) tag system for monitoring fishways. Fisheries Research 28: 253-261.

Cowx, I. G., 1999. An appraisal of stocking strategies in the light of developing country constraints. Fisheries Management and Ecology 6: 21-34.

Cucherousset, J., J. M. Roussel, R. Keeler, R. A. Cunjak \& R. Stump, 2005. The use of two new portable 12-mm PIT tag detectors to track small fish in shallow streams. North American Journal of Fisheries Management 25: 270-274.

Deverill, J. E., C. E. Adams \& C. W. Bean, 1999. Prior residence, aggression and territory acquisition in hatchery-reared and wild brown trout. Journal of Fish Biology 55: 868-875.

Dolloff, C. A., J. Kershner \& R. Thurow, 1996. Underwater observations. In Murphy, B. R. \& D. W. Willis (eds), Fisheries Techniques, American Fisheries Society, Bethesda, Maryland, 533-554.

Fausch, K. D., 1984. Profitable stream positions for salmonids: relating specific growth rate to net energy gain. Canadian Journal of Zoology 62: 441-451.

Heggenes, J., 1988. Physical habitat selection by brown trout (Salmo trutta) in riverine systems. Nordic Journal of Freshwater Research 64: 74-90.

Heggenes, J., A. Brabrand \& S. J. Saltveit, 1990. Comparison of three methods for studies of stream habitat use by young brown trout and Atlantic salmon. Transactions of the American Fisheries Society 119: 101-111.

Horton, W. D. \& T. Cochnauer, 1978. Instream flow methodology evaluation, biological criteria determination, and water quality needs for selected Idaho streams. Report 14-16-0001-77090. Idaho Department of Fish and Game, Jerome, IA.

Joyce, M. P. \& W. A. Hubert, 2003. Snorkeling as an alternative to depletion electrofishing for assessing Cutthroat and brown trout in stream pools. Journal of Freshwater Ecology 18: 215-222.

Lucas, M. C. \& E. Baras, 2000. Methods for studying spatial behaviour of freshwater fishes in natural environment. Fish and Fisheries 1: 283-316.

Maki-Petays, A., A. Huusko, J. Erkinaro \& T. Muotka, 2002. Transferability of habitat suitability criteria of juvenile Atlantic salmon (Salmo salar). Canadian Journal of Fisheries and Aquatic Sciences 59: 218228.

McMichael, G. A., T. N. Pearsons \& S. A. Leider, 1999. Behavioral interactions among hatchery-reared steelhead smolts and wild Onchorhynchus mykiss in natural streams. North American Journal of Fisheries Management 19: 948-956.

Mesa, M. G., 1991. Variation in feeding, aggression and position choice between hatchery and wild cutthroat trout in an artificial stream. Transactions of the American Fisheries Society 120: 723-727.
Ombredane, D., J. L. Baglinière \& F. Marchand, 1998. The effects of Passive Integrated Transponder tags on survival and growth of juvenile brown trout (Salmo trutta L.) and their use for studying movement in a small river. Hydrobiologia 371: 99-106.

Ovidio, M., E. Baras, D. Goffaux, C. Birtles \& J. C. Philippart, 1998. Environmental unpredictability rules the autumn migration of brown trout (Salmo trutta L.) in the Belgian Ardennes. Hydrobiologia 371/372: 263-274.

Pearsons, T. N. \& C. W. Hopley, 1999. A practical approach for assessing ecological risks associated with fish stocking programs. Fisheries 24: 16-23.

Prentice, E. F., T. A. Flagg \& C. S. McCutcheon, 1990a. Feasibility of using implantable passive integrated transponder (PIT) tags in salmonids. American Fisheries Society Symposium 7: 317-322.

Prentice, E. F., T. A. Flagg, C. S. McCutcheon \& D. F. Brastow, 1990b. PIT-Tag monitoring systems for hydroelectric dams and fish hatcheries. American Fisheries Society Symposium 7: 323-334.

Quintella, B. R., N. O. Andrade, R. Espanhol \& P. R. Almeida, 2005. The use of PIT telemetry to study movements of ammocoetes and metamorphosing sea lampreys in river beds. Journal of Fish Biology 66: 97-106.

Riley, W. D., M. O. Eagle, M. J. Ives, P. Rycroft \& A. Wilkinson, 2003. A portable passive integrated transponder multi-point decoder system for monitoring habitat use and behaviour of freshwater fish in small streams. Fisheries Management and Ecology 10: 265-268.

Rincón, P. A. \& J. Lobón-Cerviá, 1993. Microhabitat use by stream-resident brown trout: bioenergetic consequences. Transactions of the American Fisheries Society 122: 575-585.

Roussel, J. M., A. Bardonnet \& A. Claude, 1999. Microhabitats of brown trout when feeding on drift and when resting in a lowland salmonid brook: effects on Weighted Usable Area. Archiv fur Hydrobiologie 146: 413-429.

Roussel, J. M., A. Haro \& R. A. Cunjak, 2000. Field test of a new method for tracking small fishes in shallow rivers using passive integrated transponder PIT technology. Canadian Journal of Fisheries and Aquatic Sciences 57: 1326-1329.

Roussel, J. M., R. A. Cunjak, R. Newbury, D. Caissie \& A. Haro, 2004. Movements and habitat use by PITtagged Atlantic salmon parr in early winter: the influence of anchor ice. Freshwater Biology 49: 10261035.

Scruton, D. A., R. S. McKinley, N. Kouwen, W. Eddy \& R. K. Booth, 2002. Use of telemetry and hidraulic modelling to evaluate and improve fish guidance efficiency at a louve rand bypass system for downstreammigration Atlantic salmon (Salmo salar) smolts and kelts. Hydrobiologia 483: 83-94.

STATSOFT, Inc. 2004. STATISTICA (Data Analysis Software System). Version 7. www.statsoft.com. Tulsa, USA.

Steward, C. R. \& T. C. Bjornn, 1990. Supplementation of salmon and steelhead stocks with hatchery fish: a 
synthesis of published literature. Technical Report $\mathrm{n}^{\circ}$ 90-1. U.S. Fish and Wildlife Service, and Bonneville Power Administration.

Ter Braak, C. J. F., 1986. Canonical correspondence analysis: a new eigenvector technique for multivariate direct gradient analysis. Ecology 67: 1167-1179.

Ter Braak, C. J. F. \& P. Smilauer, 1998. CANOCO. Reference manual and user's guide to Canoco for Windows: Software for Canonical Community Ordination (version 4). Microcomputer Power, Ithaca, NY, USA.

Thurow, R. F. \& D. J. Schill, 1996. Comparison of day snorkeling, night snorkeling, and electrofishing to estimate bull trout abundance and size structure in a second-order Idaho stream. North American Journal of Fisheries Management 16: 314-323.

Vismara, R., A. Azzellino, R. Bosi, G. Crosa \& G. Gentili, 2001. Habitat suitability curves for brown trout (Salmo trutta fario L.) in the river Arda, Northern Italy: comparing univariate and multivariate approaches. Regulated Rivers: Research \& Management 17: 37-50.
Weber, E. D. \& K. D. Fausch, 2003. Interactions between hatchery and wild salmonids in streams: differences in biology and evidence for competition. Canadian Journal of Fisheries and Aquatic Sciences 60: 10181036.

Weber, E. D. \& K. D. Fausch, 2005. Competition between hatchery-reared and wild juvenile Chinook salmon in enclosures in the Sacramento River, California. Transactions of the American Fisheries Society 134: 44-58.

White, R. J., J. R. Karr \& W. Nehlsen, 1995. Better roles for fish stocking in aquatic resource management. In Schramm, H. L. Jr. \& R. G. Piper (eds), Uses and Effects of Cultured Fish in Aquatic Ecosystems, American Fisheries Society, Bethesda, Maryland, 527-547.

Young, M., 1999. Summer diel activity and movement of adult brown trout in high-elevation streams in Wyoming, U.S.A. Journal of Fish Biology 54: 181189. 